\title{
ANALISIS KESENJANGAN PADA PELAYANAN PENDAFTARAN TANAH PERTAMA KALI DI KANTOR PERTANAHAN KOTA BEKASI
}

\author{
Nono Sukirno ${ }^{1,2^{*}}$, Budi Mulyanto ${ }^{3}$, Dedi Budiman Hakim ${ }^{4}$ \\ ${ }^{1}$ Kantor Pertanahan \\ ${ }^{2}$ Program Pascasarjana Manajemen dan Bisnis, Institut Pertanian Bogor, Bogor 16151, Indonesia \\ ${ }^{3}$ Departemen IImu Tanah, Fakultas Pertanian, Institut Pertanian Bogor, Bogor 16680, Indonesia \\ ${ }^{4}$ Departemen Ilmu Ekonomi, Fakultas Ekonomi dan Manajemen, Institut Pertanian Bogor, \\ Bogor 16680, Indonesia
}

\section{*)E-mail:nono.sukirno03@gmail.com}

\begin{abstract}
Abstrak
Dalam rangka meningkatkan kinerja pelayanan instansi pemerintah maka pemangku kepentingan harus memperhatikan kepuasan masyarakat yang dilayaninya. Penelitian ini bertujuan untuk mengetahui tingkat kepuasan masyarakat dan selanjutnya dinalisis tingkat kesenjangan antara kinerja pelayanan dengan kepuasan masyarakat terhadap pelayanan Kantor Pertanahan. Penelitian ini dilakukan di Kantor Pertanahan Kota Bekasi, pada bulan Maret hingga Juni 2014. Desain yang digunakan dalam penelitian ini yaitu cross-sectional study. Pengambilan contoh dalam penelitian ini menggunakan teknik convenience sampling. Analisis kesenjangan diukur melalui Importance Performance Analysis (IPA). Hasil diperoleh bahwa secara keseluruhan kualitas pelayanan pendaftaran tanah yang diberikan oleh Kantor Pertanahan Kota Bekasi belum memenuhi kepuasan masyarakat. Hal ini ditunjukkan oleh selisih perolehan antara skor rata-rata kinerja sebesar 3,22 dengan skor rata-rata harapan sebesar 3,77 sehingga diperoleh skor rata-rata kesenjangan negatif sebesar $-0,55$. Hasil temuan yang lain juga menemukan bahwa terdapat indikator yang memiliki nilai kesenjangan yang tinggi antara kinerja pelayanan dengan harapan pelayanan masyarakat, yaitu indikator ketepatan waktu pelayanan. Dari temuan ters ebut, Kantor Pertanahan Kota Bekasi dapat mengambil kebijakan untuk mendisiplinkan pegawainya agar tepat waktu dalam pelayanan pendaftaran tanah.
\end{abstract}

Kata kunci: Importance Performance Analysis (IPA), kepuasan masyarakat, kinerja pelayanan, kualitas pelayanan

\section{Gap Analysis of the First Time Land Registry Services in Land Office of Bekasi}

\begin{abstract}
In order to increase service performance of government agencies, the stakeholders have to pay attention to the satisfaction of the public it serves. This study aimed to determine the level of public satisfaction and further will be analyzed the gap between service performances of the agency and public satisfaction to the service of Land Office of Bekasi City. This research was conducted at the Land Office of Bekasi City; held from March to June 2014. The design used in this study was a cross-sectional study. The samples were chosen by convenience sampling technique. Analysis of the gap was measured by Importance Performance Analysis (IPA). The results showed that the quality of land registration services that was provided by the Land Office of Bekasi City had not meet people's satisfaction. This was indicated by the difference between the average score of the service performance (3.22) and an the average score of the expectations $(3,77)$. This finding showed a gap of -0.55 that means the service performance of the agency still lower that public expectation for the services. Moreover, punctuality was indicator that that had high gap score between the service performance and public satisfaction. Therefore, Land Office of Bekasi should have a policy to discipline its employees to be on time in service of land registration.
\end{abstract}

Keywords: Importance Performance Analysis (IPA), public satisfaction, service performance, service quality

\section{PENDAHULUAN}

Pendaftaran tanah diperlukan untuk memperoleh kepastian hukum dan kepastian hak atas tanah. Pendaftaran tanah telah diatur oleh Undang-Undang. Pendaftaran tanah adalah rangkaian kegiatan yang dilakukan oleh

pemerintah secara terus menerus,
berkesinambungan dan teratur meliputi pengumpulan, pengolahan, pembukuan dan penyajian serta pemeliharaan data fisik dan data yuridis dalam bentuk peta dan daftar mengenai bidang-bidang tanah dan satuan rumah susun, termasuk pemberian surat tanda 
bukti hak dan kepemilikan atas satuan-satuan rumah susun serta hak-hak tertentu yang membebaninya. Pelaksanaan pendaftaran tanah dilakukan oleh lembaga pemerintah nonkementrian yaitu Badan Pertanahan Nasional.

Badan Pertanahan Nasional belum dapat memposisikan diri sebagai institusi pelayan publik yang akuntabel dan transparan dalam pelaksanaan tugas pengabdiannya sebagai pelayan masyarakat. Dalam upaya memberikan pelayanan kepada masyarakat Kantor Pertanahan tidak terlepas dari tuntutan masyarakat yang ada di wilayah kerjanya untuk dapat memberikan pelayanan yang berkualitas, jauh dari citra birokrasi yang berbelit belit, transparan dan lebih memperhatikan aspek keberpihakan kepada masyarakat, sehingga tuntutan akan adanya kinerja yang berkualitas merupakan suatu kebutuhan dan keharusan. Sebagai contoh dalam pengurusan sertifikat secara sporadik cenderung kurang dipahami dan diketahui oleh masyarakat karena kurangnya sosialisasi sehingga biayanya bisa melebihi dari peraturan yang telah ditetapkan pemerintah.

Berdasarkan Keputusan Menteri Pendayagunaan Aparatur Negara Nomor 63 tahun 2004 menyatakan hakekat pelayanan publik adalah memberikan pelayanan prima kepada masyarakat yang merupakan perwujudan kewajiban aparatur pemerintah sebagai abdi negara. Untuk dapat memberikan pelayanan yang memuaskan bagi pengguna layanan, penyelenggara pelayanan harus memenuhi asas-asas pelayanan sebagai berikut: transparansi, akuntabilitas, kondisional, partisipatif, kesamaan hak keseimbangan antara hak dan kewajiban.

Ukuran keberhasilan penyelenggaraan pelayanan ditentukan oleh tingkat kepuasan penerima pelayanan. Kepuasan penerima layanan dapat dicapai apabila penerima pelayanan memperoleh pelayanan sesuai dengan yang dibutuhkan dan diharapkan. Untuk menilai kinerja sektor publik menurut Mahmudi (2005) dalam kaitannya dengan kualitas layanan dipengaruhi oleh kecepatan pelayanan, kebersihan, kerapihan staf dan fasilitas, keramahan dan kesabaran staf dalam melayani pengguna layanan, staf yang membantu dan bersahabat serta perhatian pada pengguna layanan, serta keamanan dan kenyamanan. Parasuraman, Zeithaml, dan Berry (1985) juga menyebutkan bahwa ada lima kriteria dalam kualitas pelayanan yaitu tangibles, reliability, convidence dan emphaty.

responsiveness,

Beberapa penelitian telah dilakukan terkait kepuasan pelayanan terhadap pendaftaran tanah pada kantor pertanahan. Azizah (2008) menganalisis mengenai kepuasan pelayanan terhadap pendaftaran tanah pada Kantor Pertanahan di Kabupaten Bogor. Metode analisis yang digunakan dengan servqual dan rata-rata skor. Hasil penelitian yang diperoleh yaitu dimensi yang paling berpengaruh yaitu dimensi keandalan (reliability) dan emphaty. Supraworo (2009) juga meneliti mengenai analisis Indeks Kepuasan Masyarakat (IKM) terhadap kinerja pelayanan publik bidang pertanahan dalam proses balik nama di Kantor Pertanahan Kabupaten Semarang. Hasil penelitian yang diperoleh bahwa mutu pelayanan publik kantor pertanahan kabupaten semarang khususnya dalam hal proses balik nama pada peralihan hak karena jual-beli masih kurang padahal keberadan kantor pertanahan kabupaten semarang untuk pelayanan di bidang pertanahan sangat penting.

Selanjutnya, Suharno (2002) meneliti mengenai persepsi masyarakat terhadap pensertifikatan tanah (kasus di Desa Girikerto, Kecamatan Turi, Kabupaten Sleman). Hasil penelitian diperoleh bahwa persepsi masyarakat terhadap pensertifikatan tanah di Kabupaten Sleman masih bersifat negatif. Berdasarkan kajian penelitian tersebut dapat diketahui, bahwa tingkat kepuasan masyarakat terhadap suatu peleyanan dapat diukur dengan menggunakan konsep servqual yang meliputi dimensi reliability, responsiveness, assurance, empathy dan tangibles selain itu dari ketiga penetilian tersebut masih memerlukan penelitian lebih lanjut, yaitu mengenai pemodelan struktural dari kualitas pelayanan dan kepuasan masyarakat.

Penelitian yang telah dilakukan sebelumnya, belum menemukan indikator yang paling diprioritaskan untuk ditingkatkan kualitasnya. Oleh karena itu, penelitian untuk menganalisis indikator yang paling diprioritaskan dalam memperbaiki kualitas pelayanan diperlukan. Penelitian ini bertujuan untuk menganalisis tingkat kepentingan dan kinerja pegawai Kantor Pertanahan Kota Bekasi, menganalisis tingkat kepuasan masyarakat terhadap kualitas pelayanan pendaftaran tanah pertama kali di Kantor Pertanahan Kota Bekasi, dan merumuskan implikasi manajerial yang dapat direkomendasikan untuk memperbaiki kualitas pelayanan pendaftaran tanah. 


\section{METODE}

Penelitian ini dilakukan di Kantor Pertanahan Kota Bekasi, Provinsi Jawa Barat. Pengambilan data dilakukan pada bulan Maret hingga bulan Juni 2014 dengan menggunakan desain cross sectional. Penelitian ini melibatkan 125 orang masyarakat yang melakukan pendaftaran pembuatan sertifikat tanah untuk pertama kalinya di loket Kantor Pertanahan Kota Bekasi. Responden dipilih dengan teknik convenience. Data yang diperlukan dalam penelitian ini adalah data primer yaitu karakteristik responden, tingkat kepentingan dan kinerja, serta tingkat kepuasan.

Skala pengukuran yang digunakan dalam mengukur indikator dari variabel kualitas pelayanan adalah skala Likert yaitu sangat tidak puas, tidak puas, cukup puas, puas, dan sangat puas. kepuasan masyarakat terhadap pelayanan dalam kegiatan pendaftaran tanah pertama kali menjadi variabel tidak bebas $(\mathrm{Y})$, sedangkan dimensi kualitas pelayanan sebagai variabel bebas $(\mathrm{X})$, terdiri atas tangibles, reliability, responsiveness, assurance dan empathy.

Variabel tangibles (berwujud) yaitu penampilan petugas, fasilitas fisik dan peralatan yang kemudian diukur dengan menggunakan indikator-indikator sebagai berikut: kerapian penampilan petugas (X1), kenyamanan ruang tunggu (X2), kebersihan ruang tunggu (X3), sarana parkir yang luas (X4), dan tersedia papan pengumuman (X5).

Reliability (Keandalan) yaitu kemampuan Kantor Pertanahan Kota Bekasi untuk memberikan pelayanan yang dijanjikan dengan tepat dan terpercaya yang kemudian diukur dengan menggunakan indikator-indikator sebagai berikut: kejelasan informasi kegiatan pendaftaran tanah (X6), kesederhanaan prosedur pelayanan $(X 7)$, kejelasan biaya $(X 8)$, ketepatan pemeriksaan dokumen persyaratan (X9), ketepatan waktu penyelesaian (X10), kemampuan petugas (X11), dan kesiapan petugas dalam memberikan pelayanan (X12).

Responsiveness (ketanggapan) yaitu kemampuan untuk membantu penerima layanan dan memberikan pelayanan dengan cepat yang selanjutnya diukur dengan menggunakan indikator-indikator sebagai berikut: kecepatan petugas dalam memberikan pelayanan (X13), kecepatan petugas dalam menyampaikan informasi (X14), daya tanggap petugas dalam menindaklanjuti keluhan (X15), kesigapan petugas dalam menyelesaikan masalah yang terjadi (X16), kesediaan petugas dalam merespon kritik dan saran (X17), kemudahan berkomunikasi untuk memperoleh informasi (X18), dan penyelesaian sertifikat.

Assurance yaitu pengetahuan dan kesopanan pegawai serta kemampuan mereka untuk menimbulkan kepercayaan dan keyakinan yang diukur dengan menggunakan indikator sebagai berikut: kesopanan petugas dalam melayani (X19), kemampuan petugas dalam memberikan rasa aman dalam pengurusan sertifikat (X20), dan kejujuran petugas (X21).

Emphaty (empati) yaitu rasa perhatian dan kepedulian yang penuh secara personal kepada penerima layanan. Variabel ini diukur dengan menggunakan indikator sebagai berikut: perhatian petugas terhadap kebutuhan masyarakat (X22), keramahan petugas dalam memberikan pelayanan (X23), kesediaan petugas menerima keluhan dalam pelayanan (X24), dan kesabaran petugas dalam melayani (X25).

Data dianalisis dengan analisis deskriptif, Importance Performance Analysis (IPA), dan Customers Satisfication Index (CSI). Analisis deskriptif digunakan untuk menghitung nilai rata-rata dari sesetiap indikator kualitas pelayanan. IPA dan CSI digunakan untuk mengukur perbedaan antara yang diharapkan pelanggan dengan yang dipikirkan pelanggan atau perbedaan antara aspek kepentingan dengan kinerja pelayanannya. Perhitungan CSI menggunakan skor rata-rata tingkat harapan dan tingkat persepsi dari masing-masing atribut.

\section{HASIL}

\section{Karakteristik Responden}

Karakteristik responden terdiri atas jenis kelamin, usia, pendidikan, dan pendapatan. Responden dalam penelitian ini berjenis kelamin laki-laki $(61,6 \%)$ dan perempuan $(38,4 \%)$. Responden berusia kurang dari 25 tahun $(10,4 \%), 25-50$ tahun $(76,8 \%)$, dan lebih dari 50 tahun (12,8\%). Pendidikan terendah responden berada pada jenjang SD dan pendidikan tertinggi responden berada pada jenjang perguruan tinggi. Responden telah menamatkan SD $(2,4 \%)$, SMP $(5,6 \%)$, SMA $(59,2 \%)$, dan sarjana $(32,8 \%)$. Pendapatan responden kurang dari satu juta rupiah $(17,6 \%)$, satu sampai dengan dua juta $(31,2 \%)$, dua sampai dengan tiga juta $(32,2 \%)$, dan lebih dari tiga juta $(18,4 \%)$. 


\section{Kinerja dan Kepentingan Kualitas Pelayanan}

Analisis IPA menggambarkan penilaian masyarakat terhadap kualitas pelayanan pendaftaran tanah pada Kantor Pertanahan Kota Bekasi. Hasil penilaian masyarakat secara keseluruhan terhadap indikator-indikator kualitas pelayanan yang dikelompokan menjadi empat kuadran dengan garis pembagi dalam analisis tersebut adalah nilai rata-rata dari skor rata-rata kinerja (performance) yaitu sebesar 3,22 dan nilai rata-rata dari skor rata-rata kepentingan (importance) sebesar 3,77. Hasil analisis IPA disajikan pada Gambar 1.

Kuadran I (Prioritas Utama). Kuadran ini menunjukkan indikator-indikator kualitas pelayanan yang memiliki nilai kepentingan relatif tinggi sedangkan nilai kinerjanya relatif rendah. Indikator kualitas pelayanan pendaftaran tanah pada Kantor Pertanahan Kota Bekasi yang berada dalam kuadran ini, kinerjanya harus ditingkatkan dengan melakukan perbaikan secara berkesinambungan. Indikator yang berada di dalam kuadran ini, yaitu kejelasan informasi pelayanan (X6), ketepatan pemeriksaan dokumen persyaratan (X9), ketepatan waktu penyelesaian (X10), kesiapan petugas dalam pelayanan (X12), kecepatan petugas dalam menyampaikan informasi (X14), dan perhatian petugas dalam pelayanan (X22).

Kuadran II (Pertahankan Prestasi). Kuadran ini terdiri atas indikator-indikator kualitas pelayanan yang memiliki nilai kepentingan dan kinerja yang relatif tinggi. Indikator-indikator yang termasuk dalam kuadran ini dapat dipertahankan dan harus terus dikelola dengan baik karena memiliki keunggulan pelayanan dalam memberikan kepuasan masyarakat. Indikator yang termasuk dalam kuadran ini, yaitu kenyamanan ruang tunggu (X2), kebersihan ruang tunggu $(X 3)$, kemampuan petugas (X11), kesopanan petugas dalam melayani (X19), dan kemampuan petugas dalam memberi rasa aman (X20).

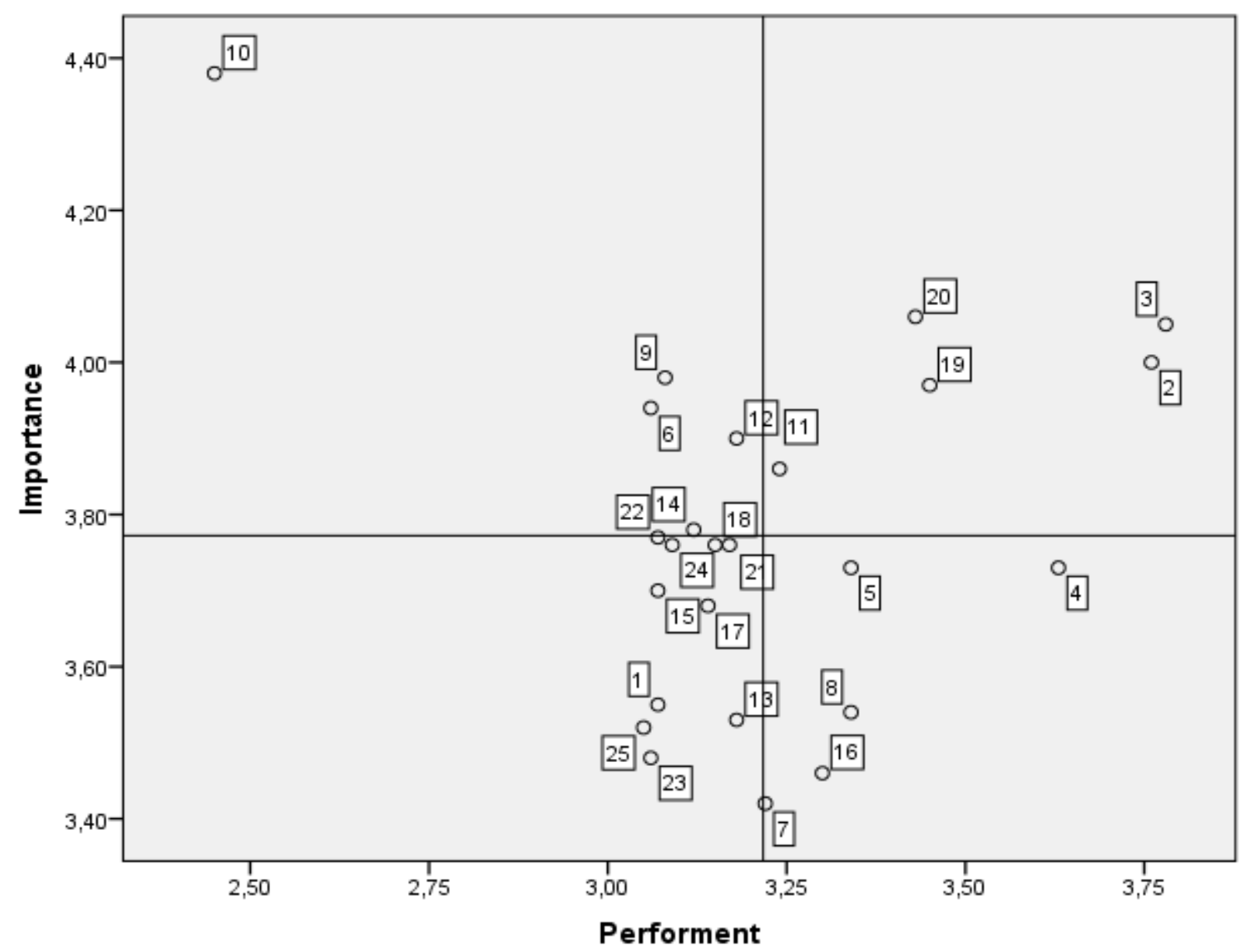

Gambar 1 Diagram kartesius kinerja dan dan kepentingan kualitas pelayanan 
Kuadran III (Prioritas Rendah). Kuadran ini memuat indikator-indikator kualitas pelayanan yang memiliki nilai kepentingan dan kinerja relatif rendah. Indikator-indikator kualitas pelayanan yang berada dalam kuadran ini tetap perlu dicermati karena kepentingan masyarakat dapat berubah dengan meningkatnya kebutuhan masyarakat terhadap jaminan kepastian hukum dan perlindungan hukum hak atas tanah. Indikator yang termasuk dalam kuadran ini, yaitu kerapian penampilan petugas (X1), kecepatan petugas dalam pelayanan (X13), daya tanggap petugas dalam menindak-lanjuti keluhan (X15), kesediaan petugas dalam merespon kritik dan saran (X17), kemudahan berkomunikasi (X18), kejujuran petugas ter-hadap kebutuhan masyarakat (X21), keramah-an petugas (X23), menerima keluhan (X24), dan kesabaran petugas dalam melayani (X25).

Kuadran IV (Berlebihan). Kuadran ini terdiri atas indikator-indikator kualitas pelayanan yang memiliki nilai kepentingan relatif rendah, sedangkan nilai kinerjanya relatif tinggi, sehingga dirasakan berlebihan oleh masyarakat. Indikator yang termasuk dalam kuadran ini, yaitu sarana parkir yang luas (X4), tersedia papan pengumuman (X5), kesederhanaan prosedur pelayanan (X7), kejelasan biaya $(X 8)$, dan kesigapan petugas dalam menyelesaikan masalah (X16).

\section{Tingkat Kepuasan Pelayanan}

Tingkat kepuasan dinilai dari nilai kesenjangan antara persepsi dan harapan. Hasil analisis tersebut diharapkan dapat memberikan masukan untuk meningkatkan kinerja petugas pertanahan. Berdasarkan hasil pengolahan data diperoleh nilai rata-rata dari indikator pembentuk dimensi tangibles, yaitu kerapian penampilan petugas (X1) dinilai tidak memuaskan dengan rentang GAP sebesar 0,48 , Ketidakpuasan masyarakat ini ditunjukkan terutama dalam cara berpakaian petugas yang dinilai kurang rapi, penggunaan kelengkapan atribut yang tidak sesuai, serta penggunaan kartu pengenal yang tidak dikenakan pada tempatnya. Indikator kenyamanan ruang tunggu (X2), mempunyai nilai kesenjangan (GAP) negatif antara kinerja dan harapan. Berdasarkan nilai kesenjangan tersebut, berarti masyarakat merasakan ketidakpuasan terhadap kenyamanan rung tunggu pelayanan. Indikator kebersihan ruang tunggu (X3) juga dinilai tidak memuaskan. Masyarakat menilai bahwa kebersihan ruang tunggu tidak terawat sehingga banyak sampah yang berceceran. Kondisi ini yang membuat kondisi ruang tunggu menjadi tidak menyenangkan. Indikator sarana parkir yang luas (X4) dinilai oleh masyarakat tidak memuaskan. Hal ini ditunjukkan oleh nilai GAP atau kesenjangan yang negatif yaitu sebesar $-0,10$. Kondisi ini disebabkan keadaan parkir yang kurang luas, sehingga parkir kendaraan masyarakan yang sedang mengurus pembuatan sertifikat tanah susah menempatkan kendaraannya. Indikator tersedia papan pengumuman (X5) keberadaannya saat ini dinilai tidak memuaskan. Masyarakat menilai bahwa papan pengumuman yang tersedia belum memuaskan masyarakat, hal ini ditunjukkan oleh nilai kesenjangan yang negatif sebesar -0.38. Kondisi papan pengumuman yang rusak dan kurang bersih, juga menjadi fatktor penentu kepuasan masyarakat.

Dimensi reliability. Kejelasan persyaratan pelayanan yang diberikan dirasakan masih sulit untuk dipahami dan dipenuhi kelengkapannya oleh masyarakat terutama dalam hal kelengkapan persyaratan berkas permohonan untuk pelayanan pengakuan hak maupun penegasan hak. Indikator $X 7$ dirasakan tidak memuaskan masyarakat dalam proses pelayanan pendaftaran tanah, karena prosedur pelayanan yang sudah disusun secara sistematis dirasakan sulit untuk dimengerti. Indikator $X 8$, dinilai tidak memuaskan masyarakat. Ketidakpuasan ini terkait dengan biaya yang dikeluarkan dalam pengurusan permohonan sertifikat. Kejelasan biaya pelayanan saat ini banyak mendapat perhatian masyarakat karena dinilai belum transparan, sehingga masyarakat sulit membedakan beberapa biaya resmi yang harus dikeluarkan dalam pengurusan permohonan sertifikat hak atas tanah. Indikator $\mathrm{X} 9$, mempunyai nilai GAP yang negatif sebesar -0.90 . Hal ini berarti bahwa pelayanan ketepatan pemeriksaan dokumen persyaratan pendaftaran tanah dinilai masyarakat masih belum puas. Ketidakpuasan masyarakat tersebut dikarenakan waktu pemeriksaan dokumen yang tidak efektif dan kurang rapi. Indikator X10, dinilai tidak memuaskan. Ketidakpuasan masyarakat terhadap ketepatan waktu penyelesaian sertifikat tanah seringkali dikeluhkan karena terbitnya sertifikat hak atas tanah terlalu lama. Indikator X11 dinilai tidak memuaskan. Kemampuan petugas dalam memberikan pelayanan sangat erat kaitannya dengan pengetahuan dan keterampilan dari petugas yang bersangkutan. Terakhir indikator X12 dinilai tidak memuaskan.

Dimensi responsiveness. Indikator X13 dinilai tidak memuaskan. Ketidakpuasan masyarakat tercermin dari lambatnya pelayanan yang diberikan kepada masyarakat. 
Indikator X14 dinilai tidak memuaskan. Ketidakpuasan masyarakat terhadap kecepatan dalam memberikan informasi pertanahan tercermin dari pemberian informasi kepada masyarakat yang masih terlalu lama dan belum sesuai dengan harapan. Indikator X15 dinilai tidak memuaskan. Ketidakpuasan masyarakat ini tercermin dari banyaknya keluhan masyarakat atas pelayanan pertanahan yang kuarang ditanggapi secara serius, sehingga timbul persepsi bahwa petugas kurang tanggap terhadap keluhan masyarakat. Indikator X16 dinilai tidak memuaskan. Penilaian ini didasarkan pada lambannya petugas dalam menyelesaikan masalah yang dihadapi masyarakat dalam pembuatan sertifikat tanah. Indikator X17, dinilai tidak memuaskan. Ketidakpuasan masyarakat tercermin dari sikap petugas yang tidak sabar dan kurang bijak dalam merespon kritik dan saran kepada masyarakat sehingga memberi kesan tidak profesional. Indikator X18 dinilai tidak puas oleh masyarakat. Hal ini ditunjukkan oleh nilai gep yang negatif sebesar -0,61. Ketidakpuasan masyarakat juga ditunjukkan oleh susahnya berkomunikasi dengan petugas, untuk memperoleh informasi mengenai kepastian biaya pembuatan sertifikat.

Dimensi assurance. Indikator X19 dinilai tidak memuaskan. Ketidakpuasan masyarakat tercermin dari penilaian intensitas pekerjaan petugas yang semakin meningkat sehingga mengurangi kesopanan sikap dari petugas dalam memberikan pelayanan. Indikator X20 dinilai tidak puas oleh masyarakat. Ketidakpuasan ini ditunjukan oleh nilai gap yang negatif sebesar $-0,62$. Selain itu, petugas kurang mampu dalam memberi rasa aman terhadap masyarakat. Hal ini ditandai dengan oknum petugas yang banyak bermain dalam besaran biaya pembuatan sertifikat tanah. Indikator X21 responden memberikan nilai tidak memuaskan, artinya kepuasan masyarakat terhadap kejujuran petugas dalam memberikan pelayanan belum terpenuhi. Ketidakpuasan masyarakat tercermin dari sikap petugas yang dinilai belum berperilaku sesuai dengan tanggung jawab dan kewenangan yang diberikan, serta tidak transparan dalam memberikan pelayanan kepada masyarakat.

Dimensi empathy. Indikator X22 dinilai tidak memuaskan, artinya kepuasan masyarakat untuk perhatian petugas dalam memberikan pelayanan belum terpenuhi. Hal ini dikarenkan perhatian petugas lebih diberikan untuk melayani staff PPAT dibandingkan melayani masyarakat pada umumnya. Indikator X23, dinilai tidak memuaskan. Ketidakpuasan masyarakat tercermin dari penilaian intensitas pekerjaan petugas yang semakin meningkat sehingga mengurangi keramahan sikap dari petugas dalam memberikan pelayanan. Indikator (X24) kesediaan petugas dalam menerima keluhan, dinilai tidak memuaskan. Ketidakpuasan masyarakat tercermin dari sikap petugas yang tidak bersedia dan kurang bijak dalam menerima keluhan masyarakat sehingga memberi kesan tidak profesional. Ketidakpuasan juga ditunjukkan oleh nilai gap yang negatif sebesar -0,67. Indikator X25 responden memberikan nilai tidak memuaskan. Ketidakpuasan masyarakat tercermin dari perilaku petugas dalam memberikan pelayanan kepada masyarakat yang memberi kesan dilakukan tidak dengan sabar.

Secara keseluruhan, kualitas pelayanan pendaftaran tanah yang diberikan oleh Kantor Pertanahan Kota Bekasi belum memenuhi kepuasan masyarakat. Hal ini ditunjukkan oleh selisih perolehan antara skor rata-rata kinerja sebesar 3,22 dengan skor rata-rata harapan sebesar 3,77 sehingga diperoleh skor rata-rata kesenjangan negatif sebesar $-0,55$. Sedangkan kesenjangan dari sersetiap dimensi ditampilkan dalam Tabel 1. Tabel 1 tersebut menunjukkan bahwa dimensi yang memiliki gap paling besar yaitu dimensi reliability sebesar $-0,78$. Nilai gap yang paling rendah yaitu dimensi tangibles sebesar -0,29. Kesenjangan negatif ini memberi arti bahwa kualitas pelayanan pendaftaran tanah yang telah diberikan oleh Kantor Pertahanan Kota Bekasi secara keseluruhan belum memberikan kepuasan bagi masyarakat. Kesenjangan negatif terjadi karena ketidaksesuaian antara kinerja mengenai pelayanan yang dirasakan dengan pelayanan yang diharapkan oleh masyarakat. Oleh karena itu, kualitas pelayanan pendaftaran tanah harus dapat ditingkatkan dalam rangka memberikan kepuasan kepada masyarakat sebagai pengguna layanan di bidang perthanan. Adapun indikator-indikator pada sesetiap dimensi yang memiliki nilai kesenjangan di bawah skor rata-rata kulitas pelayanan pendaftaran tanah adalah indikator kerapian penampilan petugas $(-0,43)$, indikator ketepatan waktu pelayanan $(-1,93)$, indikator kecepatan petugas dalam menyampaikan informasi $(-0,66)$, indikator kemampuan petugas dalam memberi rasa aman $(-0,62)$, dan indikator perhatian petugas dalam pelayanan (0,70 ). Analisis kinerja dan kepentingan (umumnya disebut sebagai harapan) terhadap kualitas pelayanan juga dilakukan dengan membandingkan rata-rata kinerja dengan rata-rata harapan pada seluruh indikator kualitas pelayanan yang diteliti. 
Tabel 1 Kesenjangan sesetiap dimensi kualitas pelayanan

\begin{tabular}{lrrr}
\hline \multicolumn{1}{c}{ Dimensi } & \multicolumn{2}{c}{ Nilai rata-rata } & \multirow{2}{*}{ GAP } \\
& Kinerja & Kepentingan & \\
\hline Tangible & 3,52 & 3,81 & $-0,29$ \\
Reliability & 3,08 & 3,86 & $-0,78$ \\
Responsiveness & 3,16 & 3,65 & $-0,49$ \\
Assurace & 3,35 & 3,93 & $-0,58$ \\
Emphaty & 3,07 & 3,63 & $-0,56$ \\
\hline
\end{tabular}

\section{Implikasi Manajerial}

Implikasi manajerial peningkatan kepuasan pelayanan yang direkomendasikan dalam penelitian ini, yaitu mengevaluasi dan menentukan kebijakan baru, seperti menambah loket pemberian informasi dan menambah petugas. Penyesuaian antara standar waktu pelayanan dengan ketepatan waktu penyelesaian sertifikat sehingga diperlukan juga untuk mengkaji ulang SPOPP. Peningkatan kualitas pelayanan juga dilakukan dengan menambah petugas untuk mempercepat proses pendaftaran tanah. Pemberian informasi pelayanan yang seluas-luasnya, melalui publikasi baik media cetak ataupun media elektronik. Dengan demikian, akan memudahkan masyarakat untuk mengakses informasi, meskipun tanpa harus datang kekantor.

\section{PEMBAHASAN}

Temuan hasil penelitian bahwa dimensi reliability memiliki nilai kesenjangan (gap) yang paling besar. Hal ini akan menjadi prioritas utama dalam penentuan kebijakan untuk meningkatkan kepuasan masyarakat. Berdasarkan temuan tersebut, maka dapat diketahui upaya prioritas perbaikan kualitas pelayanan berdasarkan dimensi kualitas pelayanan. Upaya prioritas pertama yang dilakukan oleh Kantor Pertanahan adalah pada dimensi reliability yaitu pada indikator kejelasan informasi pelayanan, ketepatan pemeriksaan dokumen persyaratan, dan ketepatan waktu penyelesaian.

Indikator pertama mengenai kejelasan informasi pelayanan. Kantor Pertanahan Kota Bekasi menyediakan sebuah loket informasi. Pada loket tersebut ditugaskan salah seorang staf untuk melayani dan menjelaskan semua informasi yang ingin diketahui oleh mayarakat berkaitan dengan proses pelayanan pendaftaran tanah. Masyarakat yang membutuhkan informasi cukup banyak sehingga harus mengantri untuk mendapatkan informasi, sedangkan petugas yang melayani hanya satu orang. Kondisi ini, membuat petugas kesulitan dan akhirnya memberikan informasi yang tidak jelas kepada masyarakat. Masyarakat yang menerima informasi tidak lengkap akhirnya memberikan respon yang kurang baik dan tidak puas terhadap pelayanan Kantor Pertanahan Kota Bekasi. Hal tersebut dapat diatasi dengan mengevaluasi dan menentukan kebijakan baru oleh pejabat yang berwenang, seperti menambah loket pemberian informasi dan menambah petugas. Selain itu, dapat dilakukan dengan menempelkan brosur mengenai prosedur pelayanan.

Indikator kedua mengenai ketepatan pemeriksaan dokumen persyaratan. Kantor Pertanahan Kota Bekasi menyediakan dua buah loket penyerahan berkas. Pada loket tersebut ditugaskan salah seorang staf untuk menerima dan melakukan pengecekan berkas permohonan pelayanan pendaftaran tanah. Berkas permohonan masyarakat yang masuk sesetiap harinya cukup banyak, sedangkan petugas yang melayani hanya ada satu orang. Kondisi tersebut sebenarnya tidak memengaruhi ketepatan petugas loket tersebut untuk melakukan pengecekann berkas permohonan. Tetapi permasalahan baru muncul pada saat masyarakat harus menunggu lebih lama untuk menyerahkan berkas permohonannya. Kondisi inilah yang membuat masyarakat merespon pelayanan pendaftaran tanah kurang puas. Pejabat yang berwenang harus menambah petugas untuk penerimaan berkas, agar proses pengecekan dokumen tidak terlalu lama. Hal tersebut sesuai dengan pilar pelayanan prima, yang mengedepankan ketepatan dan kecepatan dalam menyelesaikan tugas.

Indikator ketiga mengenai ketepatan waktu penyelesaian sertifikat. Jangka waktu penyelesaian sertifikat tanah melalui kegiatan pendaftaran tanah pertama kali secara sporadik telah diatur dalam SPOPP. Akan tetapi kenyataannya masih banyak masyarakat menilai pelayanan sertifikat membutuhkan waktu yang lama dan ketepatan waktu penyelesaian sertifikat dipersepsikan negatif. Oleh karena itu, perlu dilakukan upaya perbaikan untuk meningkatkan kepuasan masyarakat. Hanya saja, ketepatan waktu penyelesaian sertifikat tersebut sangat tergantung dengan kelengkapan persyaratan administrasi yang harus dipenuhi oleh masyarakat, terutama untuk keperluan pendaftaran hak-hak lama yang membutuhkan kelengkapan data yuridis dan alat-alat bukti kepemilikan mengenai adanya hak tersebut 
berupa bukti-bukti tertulis, keterangan saksi dan atau pernyataan yang bersangkutan. Selain itu diperlukan partisipasi masyarakat di dalam proses penetapan hak atas tanah yang sangat penting terutama dalam mendorong masyarakat untuk dapat memberikan data yuridis dan data fisik kepemilikan hak atas tanah yang benar sesuai dengan kenyataan yang sebenarnya di lapangan.

Hal ini sesuai dengan pendapat Adnan (2007) yang menyatakan bahwa jangka waktu pelayanan pertanahan untuk pendaftaran tanah pertama kali sudah diatur dalam SPOPP, tetapi dalam implementasinya di lapangan banyak masyarakat menilai bahwa kesesuaian waktu standar dengan waktu pelayanan riilnya masih jauh dari harapan, sehingga kepastian waktu penyelesaian sertifikatpun belum sesuai dengan harapan. Hal ini oleh masyarakat menilai negatif terhadap pencapaian kinerja Kantor Pertanahan. Hasil tersebut diperjelas dengan pendapat Ratminto dan Winarsih (2006), yang mengemukakan bahwa untuk memenuhi kebutuhan informasi pelayanan kepada masyarakat, sesetiap unit pelayanan instansi pemerintah wajib mempublikasikan mengenai prosedur, persyaratan, biaya, waktu, dan lain-lain serta pejabat yang berwenang dan bertanggung jawab. Publikasi dan atau sosialisasi tersebut di atas dapat dilakukan melalui media cetak (brosur, leaflet, booklet), media elektronik (website, home page, situs internet, radio, TV), media gambar dan atau penyuluhan secara langsung kepada masyarakat.

Selain itu menurut hasil penelitian Purwanto (2012) menunjukkan bahwa indikator yang masih rendah dalam pelayanan di Kantor Pertanahan Kabupaten Semarang, yaitu prosedur pelayanan, persyaratan, kejelasan petugas, dan kedisiplinan petugas. Dariah (2008) menunjukkan bahwa faktor-faktor kualitas pelayanan jasa yaitu keandalan, daya tanggap, kepastian, empati, dan bukti fisik baik secara parsial ataupun simultan mempunyai pengaruh yang signifikan terhadap kepuasan masyarakat pada Kantor Pertanahan Kota Banjarmasin. Dimensi keandalan mempunyai pengaruh paling kuat terhadap kepuasan masyarakat pada Kantor Pertanahan Kota Banjarmasin. Dari dua penelitian tersebut bahwa ada perbedaan hasil dengan penelitian di Kantor Pertanahan Kota Bekasi, yaitu dalam hal dimensi dan indikator yang paling diprioritaskan untuk ditingkatkan kualitasnya.

Temuan dimensi yang menjadi prioritas perbaikan kualitas pelayanan dalam penelitian ini berbeda dibandingkan dengan temuan sebelumnya seperti Sutadi (2008), Kuncoro (2008), Supraworo (2009), Cahyanto (2011), dan Riyadi, Hermawan, dan Sumarwan (2015). Menurut Sutadi (2008) dan Riyadi, Hermawan, dan Sumarwan (2015) peningkatan kualitas pelayanan pada dimensi tangibles dan emphaty diperlukan untuk meningkatkan kepuasan masyarakat. Sementara itu, dimensi emphaty juga ditemukan sangat berpengaruh terhadap kepuasan masyarakat di Kantor Pertanahan Kabupaten Semarang Supraworo (2009) dan Kabupaten Jepara (Cahyanto 2011). Selanjutnya, Kuncoro (2008) menemukan bahwa indikator dalam dimensi tangible yaitu sarana dan prasarana kantor memberikan kontribusi yang paling besar dalam meningkatkan kualitas pelayanan. Berdasarkan temuan penelitian dan analisis dengan membandingkan dengan temuan sebelumnya maka kualitas pelayanan perlu ditingkatkan sehingga masyarakat sebagai pengguna jasa menjadi puas. Aspek yang perlu ditingkatkan adalah dimensi reliability namun dimensi lain juga tetap ditingkatkan kualitasnya,

\section{SIMPULAN DAN SARAN}

Berdasarkan hasil penelitian diperoleh dimensi kualitas pelayanan pendaftaran tanah secara keseluruhan kualitas pelayanan pendaftaran tanah yang diberikan oleh Kantor Pertanahan Kota Bekasi belum memenuhi kepuasan masyarakat. Indikator-indikator dari setiap dimensi yang memiliki nilai kesenjangan dibawah skor rata-rata kulitas pelayanan pendaftaran tanah adalah indikator kerapian penampilan petugas, indikator ketepatan waktu pelayanan, indikator kecepatan petugas dalam menyampaikan informasi, indikator kemampuan petugas dalam memberi rasa aman, dan indikator perhatian petugas dalam pelayanan. Indeks kepuasan diperoleh pada rentang 61 persen hingga 80 persen yang berarti secara keseluruhan masyarakat merasa cukup puas terhadap kinerja pelayanan Kantor Pertanahan Kota Bekasi.

Beberapa alternatif kebijakan yang dapat ditempuh oleh Kepala Kantor Pertanahan Kota Bekasi, yaitu mengevaluasi dan menentukan kebijakan baru, seperti menambah loket pemberian informasi dan menambah petugas, penambahan jumlah pegawai untuk penerimaan berkas, agar proses pengecekan dokumen tidak terlalu lama, dan perlu adanya penyesuaian antara standar waktu pelayanan dengan ketepatan waktu penyelesaian sertifikat. Oleh karena itu, perlu mengkaji ulang SPOPP. 


\section{DAFTAR PUSTAKA}

Adnan, M. A. \& Subandi, F. A. (2007). Akutansi mutu terpadu (total quality accounting). Yogyakarta, ID: UPP AMP YKPN.

Azizah, N. (2008). Analisis kepuasan terhadap pelayanan pendaftaran tanah (kasus: Kantor Pertanahan Kabupaten) (tesis). Program Magister Manajemen Agribisnis, Institut Pertanian Bogor, Bogor.

Cahyanto. (2011). Persepsi pelanggan terhadap pelayanan publik di kantor pertanahan: Kantor Pertanahan Kabupaten Jepara (tesis). Program Magister Manajemen dan Bisnis, Institut Pertanian Bogor, Bogor.

Dariah. (2008). Pengaruh kualitas pelayanan terhadap kepuasan masyarakat dalam mengurus sertifikat tanah pada kantor pertanahan: Kantor Pertanahan Kabupaten Banjarmasin. Jurnal Media Mahardika, 12(7).

Kuncoro. (2008). Kepuasan masyarakat terhadap kualitas pelayanan pendaftaran tanah sistematik: Kantor Pertanahan Kota Depok (tesis). Magister Manajemen dan Bisnis, Institut Pertanian Bogor, Bogor.

Mahmudi. (2009). Manajemen kinerja sektor publik (penerapan citizen's charter dan standar pelayanan minimal). Yogyakarta, ID: Pustaka Pelajar Yogyakarta Penerbit UPP AMP YKPH.

Parasuraman, A., Zeithaml, V. A., \& Berry L. L. (1985). A conceptual model of services quality and its implication for future research,. Journal of Marketing, 49(1), 4150.

Purwanto. (2012). Analisis faktor-faktor yang memengaruhi kualitas pelayanan pengurusan sertifikat tanah di kantor pertanahan: Kantor Pertanahan Kabupaten Tulung Agung. Jurnal IImu Manajemeismain, 1(1).

Ratminto. \& Winarsih, A. S. (2005). Manajemen pelayanan pengembangan model konseptual. Jakarta, ID: Pustaka Setia.

Riyadi, S., Hermawan, A., Sumarwan, u. (2015). Kepuasan masyarakat terhadap kualitas pelayanan Kantor Pertanahan Kabupaten Indramayu. Jurnal IImu Keluarga \& Konsumen, 8(1), 49-58.

Suharno. (2002). Persepsi masyarakat terhadap pensertifikatan tanah (kasus di Desa Girikerto Kecamatan Turi Kabupaten Sleman). Jurnal Pertanahan, 2.

Sutadi. (2008). Analisa kepuasan pelayanan pendaftaran tanah di kantor pertanahan Kota Jambi Provinsi jambi (tesis). Magister Manajemen dan Bisnis, Institut Pertanian Bogor, Bogor.

Supraworo, J. (2009). Analisis indeks kepuasan masyarakat (IKM) terhadap kinerja pelayanan publik bidang pertanahan dalam proses balik nama pada peralihan hak karena jual-beli di Kantor Pertanahan Kabupaten Semarang (tesis). Universitas Diponegoro, Semarang. 